\title{
THE USE OF ORIGAMI IN TEACHING WRITING PROCEDURE TEXT OF THE SECOND GRADE AT SMA MUHAMMADIYAH MATARAM IN ACADEMIC YEAR 2016/2017 \\ ${ }^{(1)}$ Moh. Fauzi Bafadal ${ }^{\text {(2) }}$ Rizka Afrilina
}

${ }^{(1)}$ Lecturer of English Department Muhammadiyah University of Mataram

${ }^{(2)}$ Students of English Department Muhammadiyah University of Mataram

\begin{abstract}
Origami is a kind of method for teaching language through dialogues which stresses on the students' habit formation by repetition, memorizing grammatical structures through substitutions, singular-plural and tense transformations etc, using the target language and the culture where the language is spoken. The objective of this research was to find out the effect of Origami in teaching writing procedure text. Method design this research was true expriment research used experimental method. The population of this research were the second year students of SMA Muhammadiyah Mataram in Academic year 2016/2017, This study the writer taken all population as sample consist of 38 students. Because the population less that 100. They divided into two classes, namely experimental class 21 and control class 17 . The writer collected the data using testing method pre and post test. According Hughes rubric and $t$-test formula theory. The result of this research showed that mean score of experimental group 9.5 and mean score of control group 2.9. Based on t-test itshowed that $t-$ value 11.9 and after cosulting to $t$-table, the $t$-value was higher than $t$ table. To conclude origami teaching and learning is more effective to improve students' writing procedure text, this can be seen from the results of test score, it shows that the experimental class which was given treatment using origami teaching and learning got higher score than control class without taught by used origamil teaching and learning method. Besides the the origami could improve the students' motivation, the origami could attract the students' attention, the origami help the students to memorize the vocabulary and the origami make the teaching and learning activities interesting. Presentation in which the writer presented the materials by using origami as media the students clearly and easily to understand.The writer concluded that Origami can warning up the student that was done to make students interested in learning writing procedure text and has positive effect in teaching writing procedure text.
\end{abstract}

KeyWords: Origami,Procedure text,Writing 


\section{Introduction}

Origami is the art of paper folding originated from Japan and has been commonly practiced worldwide. It derived its name from the Japanese word 'oru' as in 'to fold', and kami' as in 'paper'. Whenever origami is mentioned, first thing comes in people mind might usually be 'paper crane' or even 'children activity'. It conventionally perceived as just a kind of art rather than something offer practical usage. Over the years, origami has intrigue many artists and scientist to investigate and reveal its underlying principles.Margalit Fox (April 2, 2005).

Writing also is transforming thoughts into language; it means that we need to think about the content of our writing first and then arrange the ideas using appropriate language (e.g. grammar and vocabulary). Consequently we must learn about organizational skills in writing (Harsyaf et al: 2009).Nunan $(2003 ; 88)$ also gives other ideas that : writing is the process of thinking to invent ideas, thinking about how to express into good writing, and arranging ideas into statement and paragraph clearly. It indicate that the learners are expected to explore the ideas and make them into good written.

Writing is an important part of the curriculum in schools from the earliest grades onward, and that most children in countries that have a formal education system will learn to write, at least at a basic level, in that setting. in this sense, we can say that first language writing instruction is relatively standardized within a particular culture (Weigle, S. C., 2002:5).

Procedure isa factual text designed to describe how something is accomplished through a sequence of actions or steps. The text structures consist of goal that followed by a series of steps oriented to achieve the goal (Harsyaf 2009:12). Procedure text is a text that is designed to describe how something is achieved through a sequence of action or steps. It explains how people perform different processes in a sequence of steps. This text uses simple present tense, often imperative sentences. It also use the temporal conjunction such as first, second, then, next, finally, etc (Nurliaenda 2009:2:23) furthermore, (Widda at al 2009:35) state that a procedure text is a text used to describe how something is conducted through a sequence of action or step, which applies present tense and often imperative sentence. It also uses temporal conjunctions.

\section{METHOD}

The research design of this study is True Experimental Design.The kind of this study was quantitative study, where they will be randomization between control and experimental group or called as pretest-posttest control group design (Sugiono, 2010).They are treated in different ways, the experimental group would be teach by using origami in their learning activities and the control group would not teach by using origami.

The population of this research would two classes of students at SMA MuhammadiyahMataram with the total of population are 38 students.

The researcher takes 2 classes at the second year are XI IPA and XI IPS where is XI IPS students as experiment group (with treatment ) and XI IPA students as control group (without treatment ). In other word, the researcher takes 38 students. 
The researcher uses origami in teaching writing procedure text test as the instrument of the research.The test in this study source of internet namely mini test.Researcher provided mini test which consists of eight test for each group to measure theachievement or capability of the individual or group.Researcher wouldusedorigamias anaid at this evaluation test with the topic" How to make crane, boat, hat, fish" forexperiment group and control group the researcher give same test but would not teach by using origami Afterthat, they practiced, and then wrote the procedure text based thetopic.So the researcher gets the data from evaluation testwhich is applied using origami.

In this research, the data would be taken based on the following steps:

1. Pre- test

The first step in gathering the data is by giving the students pre-test.

2. Treatment, teaching writing by using origami.

The writer gave the treatments for experimental group used origami.

3. Pos-test

In the last, the writer gave the post test to experimental and control group.

\section{RESEARCH FINDING}

This chapter presents about the analysis of the data concerning the skill at the second grade students of SMA MUHAMMADIYAH MATARAM in academic year 2016/2017. In the analysis data, the writer used origami in teaching writing procedure text test as the instrument.

After getting the score deviation of pre-test and post-test, then the next step was the calculation of mean score of the two groups. It can be formulated as follows:

a. The calculation of mean score

1. The mean score of experimental group $(\mathrm{Mx})$

$$
\begin{aligned}
& \mathrm{Mx}=\frac{\sum x}{N} \\
& \mathrm{Mx}=\frac{200}{21} \\
& \mathrm{Mx}=9,5
\end{aligned}
$$

2. The mean score of control group (My)

$\mathrm{My}=\frac{\Sigma y}{N}$

$\mathrm{My}=\frac{50}{17}$

$$
\mathrm{My}=2,9
$$

b. The computation of deviation

1. Square deviation of experimental group

So, $\sum \mathrm{X}=\sum \mathrm{x}^{2}-(\mathrm{x})^{2}$

$\mathrm{Nx}$

$$
\begin{aligned}
& X^{2}=2550-\frac{(200)^{2}}{21} \\
& X^{2}=2550-\frac{40,000}{21}
\end{aligned}
$$




$$
\begin{aligned}
& X^{2}=2550^{-1904} \\
& X^{2=} 646
\end{aligned}
$$

2. Square deviation of control group

$$
\begin{aligned}
& \sum \mathrm{Y}=\sum \mathrm{y}^{2}-(\mathrm{y})^{2} \\
& \mathrm{Y}^{2}=250-\frac{(50)^{2}}{17} \\
& \mathrm{Y}^{2}=250-\frac{2,500}{17} \\
& \mathrm{Y}^{2}=250-147 \\
& \mathrm{Y}^{2}=103
\end{aligned}
$$

\subsubsection{The Calculation of t-test}

After finding square deviation, the result of data analysis score is calculated to the score of t-test formula.

$$
t-\text { test }=\frac{\mathrm{Mx}-\mathrm{My}}{\sqrt{\frac{\sum x^{2}+\sum y^{2}}{(\mathrm{Nx}+\mathrm{Ny})-2}\left[\frac{1}{\mathrm{Nx}}+\frac{1}{\mathrm{Ny}}\right]}}
$$

Where: $\quad$ M: The mean score of each group

$\mathrm{N}$ : The number of sample

$\mathrm{X}$ : The standard deviation score of control group

Y: the standard deviation score of control group

$\sum$ : the sum of......

$\sqrt{ }$ : the root of....

(Arikunto, 2010: 306)

$$
\begin{aligned}
& t-\text { test }=\frac{\mathrm{MX}-\mathrm{MY}}{\sqrt{\frac{\sum x^{2}+\sum y^{2}}{(\mathrm{NX}+\mathrm{NY})-2}\left[\frac{1}{\mathrm{NX}}+\frac{1}{\mathrm{NY}}\right]}} \\
& \mathrm{t}=\frac{9,5-2,9}{\sqrt{\frac{646+103}{(21+17)-2}\left[\frac{1}{21}+\frac{1}{17}\right]}} \\
& t=\frac{12,4}{\sqrt{\left[\frac{749}{36}\right]\left[\frac{2}{38}\right]}} \\
& \mathrm{t}=\frac{12,4}{\sqrt{20,8[0,05]}} \\
& \mathrm{t}=\frac{12,4}{\sqrt{1,04}} \\
& \mathrm{t}=\frac{12,4}{1,04} \\
& \mathrm{t}=11,9
\end{aligned}
$$


The analysis of the data in this research is aimed to find out the deviation mean scores analysis it is referred to the score of t-test $11.9 \mathrm{Now}$, it is to be interpreted to find out if it is significant or not.

Before the writer check the table of distribution. Firstly, the writer determines the degree of freedom (df) that is $x+y-2=21+17-2=36$. Based on the table of level significance have been pointed out, the coefficient t-test is directly checked on the table of $t$ distribution. Based on the table, the critical value of t-table on the level of significance $t 0.05 \%$ is 2.02 and $t 0.01 \%$ is 2.70 . So it is found that $11.9>2.02$ and 2.70.

Based on the data analysis above, it was found that the result of t-test is higher than t-table. It means that alternative hypothesis which stated that the use origami has effect in teaching writing procedure text is accepted. Meanwhile the null hypothesis which stated that use origami has not effect in teaching writing procedure text is rejected.

\section{Discussion}

Based on the result of analysis of the deviation score of pre-test and post-test, then it is continued to the calculation the computation of the mean scores. Since the two groups were evaluated using the same test, then we can see from the mean score is that greater obtained by certain group, the better of achievement, or vice versa. It can be interpreted that the mean score of the groups is 2.9 for control group and 9.5 for experimental group. Experimental group is better than control group although it is only a temporary assumption. So it can be concluded that using origami can motivated the students to involve actively in learning writing procedure text in class. The students were also active, and enthusiast in their activities in classroom. As example when the writer gave the pre-test about how make a cup coffee, tea, the students designed to describe how something is accomplished through a sequence of action or steps (Appendix Pre-test Rismanika) but after the treatment she start to like English subject and when the writer gave post-test about make an origami fish, heart she really gave a good answer and grammatical sentences like "The first, paper folding origami in two evenly after that the fold back triangular direction (Appendix IV Post-test Nia Ramdani Yarta). Besides, The first meeting writer taught origami crane the students lose motivation and bored to study English applying origami. Because ,they less vocabulary. Consequence they difficulties explain the steps of origami in writing procedure text grammatically correct and they also confused talked making process origami in front of classroom by used good communication grammatically correct. But the second meeting the writer taught origami heart and types other the students fun and got new vocabulary. They confident explain the steps of origami in writing procedure text and talked making process origami heart by used good communication grammatically correct. Origami is a kind of method for teaching language through dialogues which stresses on the students' habit by repetition, memorizing, grammatical structure through substitutions, singular-plural and sense transformation(Fei and Sujan, 2013:1)

Finally, the findings on interaction effect of OrigamiTeaching writing procedure text using origami can be enjoyable for both teacher and students. In fact, students can 
improve their writing procedure text after being taught using origami.Origami is one of the appropriate methods in teaching English especially in teaching writing procedure text process. Besides that, teaching writing procedure text which is using origami can make students more enthusiastic, excited and happy in learning writing procedure text process.

\section{Conclusion}

Based on result of the study, it could be concluded that the use of origami has an effect in teaching writing procedure text. This skill has been proved by analyzing data from the result between the deviations of mean scores of experimental group was 9.5 and control group was 2.9.It after being taught using origami it can be seen by students' achievement of writing score in experiment group. Students' writing after being taught using origami was improved as well as their motivation to learn English. They become more understood in writing procedure text and got new vocabulary. Results of the research showed that the students also improved their writing. They become better in composing and arranging procedure text effectively and efficiently. Finally the use of origami in teaching writing procedure text at second grade students of Muhammadiyah Mataram has effect. Origami as a method in teaching writing procedure text because student can be mentally alert after learning process. This method is recommended for a teacher to teach procedure text because it covers all the necessary step in effective learning order. The origami steps give student the opportunity to see and listen the detail to do or make something then they write the procedure text.

\section{Suggestion}

Based on the conclusion above, there were some suggestions that were proposed by the writer:

\section{The Teacher}

a. Teacher must try a new way or method to create conducive situation in the class. An enjoyable relationship between teacher and students is the most important thing in teaching learning activities. So that, both of teacher and students will get success together through a good communication.

b. Teacher Teaching writing procedure text using demonstration for Second grade students of SeniorHigh School is not easy as we thought, there are many difficulties both of teacher and students had. The second grade students of Senior High School are categorized children at transition period. They often bored and sometimes lose their motivation to study English. As a professional teacher, we must push their enthusiasm and motivation always in teaching learning English by several ways as well as we can.

2. The students

a. Students having to used Origami when describe something to get good written and be able to express much ideas.

b. Students would get confident in use origami because they could written over based on the topic. 


\section{BIBLIOGRAPHY}

Arikunto, S. (2013). Prosedur Penelitian Suatu Pendekatan Praktek. Jakarta: RinekaCipta.

A.S. Hornby, Oxford Advanced Learners' Dictionary, (NY: Oxford University Press, 1987), p. 1234.

Action Research: An Educational Leader's Guide to School Improvement, (Norwood: Christoper- Gordon Publication, Inc., 1998), p.8.

Anthology of Current Teaching,Cambridge : University Press.

Brown, H. D. (2004). Electric Journal of Foreign Language Teaching, Harlow: Longman.

Bram, Barli. 1995. Writing Well, Improving Writing Skill. Yogyakarta: Kanisius.

Fei and Sujan, (2013). Origami Theory and Its Application: A Literature Review. International Journal of Sosial. Volume:7, number 1

Fitriyah, E.(2012/2013). Skripsi: The Use ofOrigamiToImprove SpeakingSkill The EighthGrade StudentsofSMPN2 NalumsariJepara In The Academic 2012/2013.

Harsyaf et al (2009) Teaching Writing: Better Education Through Reformed Management and Universal Teacher Upgrading: Center for Development and Empowerment of Teachers and Education Personnel.

Hughes, Arthur. (2003). Testing For Language Teachers. Cambridge: Cambridge University press.

Harmer, J. 2004. How to Teach Writing. New York: Addison Wesley Publishing Company.

Harmer, J. 1998. How to Teach English. Pearson Education Limited.

Ha.Depan-2 pdf- foxit reader-( Ha.Depan-2 pdf)

Hal-Judul-pdf reader (Hal-Judul pdf)

Horland, Retrieved on Friday, March $12^{\text {th }} 2010$ at 16.05 from

Irene,Y.(2005). The impact of origami workshops on students' learning of geometry. The University Hong Kong.

Jack Richards and friends, Longman Dictionary of Applied Linguistics, (England: Longman, 1990), p.292.

Jazebi, S. (2012). A Thesis: Origami, Kirigami, and The Modeling of Leaves: An Interacture Computer Application.

Linse, Caroline T, Practical English Language Teaching: Young Learners, NY: Mc Graw Hill, 2006

Mukarto, Sujatmiko, Jossephine S.M., Widya K. 2006. English On The Sky For The Junior High School Students Year IX. Erlangga

Marguerite Ann Snow and Donna M. Brinton. The Content-Based Classroom. (New York: Longman Published,1997),p.29.

Mark Anderson and Kathy Anderson, Text Types in English 1, (South Yarra: Machmillan Education Malaysia,1997),p.1-3.

Nunan, David. (2003). Practical English Language Teaching. New York: The Mograw-Hill.

OtongSetiawanDjuharie, GENRE, (Bandung: CV. YramaWidya, 2008), page. 39. 
Richard, Jack and Willy A. Renandya, Methodology in Language Teaching: An Sugiyono, (2010). MetodePenelitianPendidikan.Cet. XII; Bandung: Alfabet.

SuharsimiArikunto, ProsedurPenelitian: SuatuPendekatanPraktik, (Jakarta: PT. RinekaCipta, 2006), $6^{\text {th }}$

Starley, D. 1997 Metallurgical study of a Roman iron beam from the 1959 by-pass excavations, Catterick, North Yorkshire Ancient Monuments Laboratory Report89/97.

Swales, J. M. (1990). Genre analysis: English in academic and research settings. Cambridge, Cambridge University Press

Taylor, G. (2009) A Student's Writing Guide. Cambridge University press.

Urquhart V. and McIver M, (2005). Teaching Writing in the Content Areas. Association for Supervision and Curriculum Development

Widda, TN.,Yuniarti D., Arini and Sugeng, A. 2009. PR Bahasa InggrisUntuk SMP/MTs.Klaten:IntanPariwara.

Weigle S. C, (2002). Assessing Writing. The Cambridge language assessment series. Zenger(1997;68) fifty strategies for teaching english language learners and edition New Jersey; pearsonmerill prentice hall. 